\title{
Encapsulation of Fe Particles in Carbon Cages using Both Surface Wave Plasma and Arc Discharge Techniques
}

\author{
D. Sugimori, Y. Nakayama, J. Fujita, T. Yamauchi*, Y. Fujiwara*, and M. Jimbo \\ Daido Institute of Technology, Takiharu 10-3, Minami-ku, Nagoya 457-8530, Japan \\ "Mie University, Kurima-machiya-cho 1577, Tsu 514-8507, Japan
}

\begin{abstract}
Fine Fe particles encapsulated in carbon cages were synthesized by employing both arc and surface wave plasma discharge techniques. The size of synthesized nanocapsules ranged from several $10 \mathrm{~s} n \mathrm{~m}$ to $10 \mu \mathrm{m}$ in diameter, which was approximately one order of magnitude larger than that of nanocapsules synthesized by the arc discharge method. The transmission electron micrographs revealed that the Fe particles were encapsulated in graphite shells. The selected-area electron diffraction patterns indicated that the Fe particles were single crystals. The fraction of a-Fe, g-Fe and $\mathrm{Fe} 3 \mathrm{C}$ components in the nanocapsules synthesized under the total gas pressure of $1.0 \mathrm{kPa}$ were estimated to be $83,6,11 \mathrm{wt} \%$, respectively.
\end{abstract}

Key words: carbon nanocapsule, surface wave plasma, single crystal

\section{表面波プラズマとアーク放電を用いた $\mathrm{Fe}$ 微粒子内包カーボンナノカプセルの合成とその磁気特性}

\author{
杉森大祐・中山洋輔・藤田順治・山内俊和* ・藤原裕司 ${ }^{*} \cdot$ 神保睦子 \\ 大同工業大学，名古屋市南区滝春町 10-3( ₹ 457-8530) \\ *三重大学，三重県津市栗真町屋町 1577（テ514-8507）
}

\section{1.はじめに}

アーク放電により $\mathrm{LnC}_{2}$ の微粒子を内包したカーボンナノカプ セルの合成が報告されて以降 1-2), 様々な金属微粒子内包力ーボン ナノカプセルが合成され，その特性が研究されてきた．特に磁性 金属微粒子を内包したカーボンナノカプセルは, 磁気テープなど 磁気記録材料への応用を念頭において，精力的にその磁気特性や 構造の研究がなされている ${ }^{3-5)}$. また, 近年では高周波での利用を 前提として, $\mathrm{Ni}$ 微粒子内包カーボンナノカプセルの $\mathrm{GHz}$ 領域で の透磁率などの研究も行われており 6), 今後, 磁性金属微粒子内包 カーボンナノカプセルの応用分野がさらに広がっていくことが期 待できる.

現在までに報告されているカーボンナノカプセルの多くは炭素 電極間でのアーク放電法により合成されており, その粒径は数 $\mathrm{nm}$ から数 $100 \mathrm{~nm}$ 程度である. この方法で合成されるナノカプセルに は金属微粒子とともに炭化物微粒子も内包される.これは，通常 のアーク放電法では, 金属材料を埋め込んだ炭素電極を陽極とし て，炭素と金属を同時に蒸発させてナノカプセルを合成している ためであると考えられる. 特に $\mathrm{Fe}$ を内包させた場合, $\mathrm{Fe}{ }_{3} \mathrm{C}$ 微粒 子を内包したカーボンナノカプセルが合成される割合が大きくな る. Hihara らは, 500-600 Torr の He ガス圧下でアーク放電法によ り $\mathrm{Fe}$ 微粒子内包カーボンナノカプセルを合成した場合, $\alpha-\mathrm{Fe}$, $\mathrm{Fe}_{3} \mathrm{C}$ の含有量はそれぞれ $60 \%$ ，20\%であると報告している4). また, Masuda らは 5 気圧の $\mathrm{He}$ 中で同様に $\mathrm{Fe}$ 微粒子内包カーボン ナノカプセルを合成した場合， $\alpha-\mathrm{Fe} ， \mathrm{Fe}_{3} \mathrm{C}$ の含有量はそれぞれ $45 \mathrm{wt} \% ， 30 \mathrm{wt} \%$ であると報告している5).

今回, 我々は炭化物微粒子の形成をおさえて, より多くの金属 微粒子を合成するために，アーク放電法で用いられる金属 - カー ボン複合陽極を用いず，金属電極間のアーク放電および表面波プ
ラズマを利用する方法で， Fe 微粒子内包カーボンナノカプセルを 合成し，その構造および磁気特性を評価したので報告する.

\section{2. 実験方法}

本実験で使用したカーボンナノカプセルの合成装置の概略図を Fig. 1 に示寸. チャンバの上部石英ガラス空より $2.45 \mathrm{GHz}$ のマイ クロ波が導入できるようになっている．また，アーク放電に用い た Fe 電極の純度は 99.9 \%である. 具体的な Fe 微粒子内包力ーボ ンナノカプセルの合成手順は以下の通りである.

（1）ロータリーポンプにより，5 Pa 以下まで排気.

（2）チャンバ内圧力が $0.5 \mathrm{kPa}$ になるまで $\mathrm{Ar}$ ガスを導入.

（3）マイクロ波 $(200 \mathrm{~W})$ により表面波プラズマを生成.

(4) $\mathrm{CH}_{4}$ ガス $(20 \mathrm{sccm})$ を導入し $\mathrm{Ar}+\mathrm{CH}_{4}$ プラズマを生成.

(5) $\mathrm{Ar}+\mathrm{CH}_{4}$ ガス圧 $\left(P_{\text {total }}\right)$ をメインバルブにより調整.

(6) $\mathrm{Fe}$ 電極間のアーク放電により, Fe を蒸発. 本実験では $P_{\text {total }}$ を 0.6 から $1.5 \mathrm{kPa}$ まで変化させた. また，アー ク放電電流 $\left(I_{\text {arc }}\right)$ は $0.5 \mathrm{~A}$ とた.

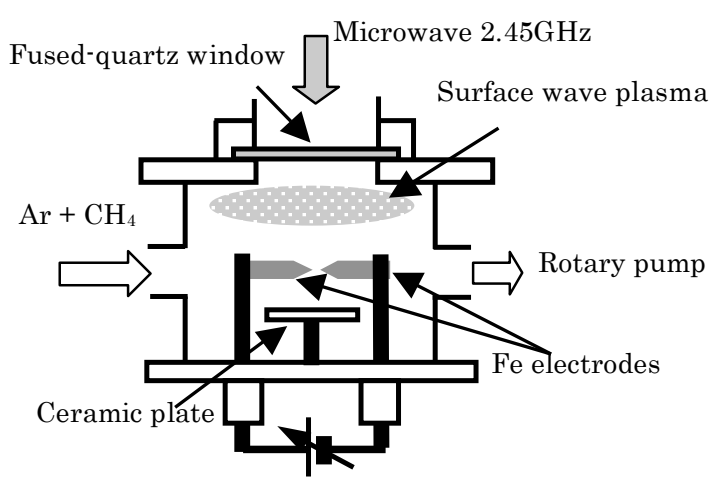

Fig.1 Schematic of the synthesizing reactor. 
この方法では, $\mathrm{Fe}$ 電極から蒸発した $\mathrm{Fe}$ が微粒子化し, $\mathrm{Ar}+\mathrm{CH}_{4}$ プラズマ中で $\mathrm{Fe}$ 微粒子表面がカーボンで覆われることによって, $\mathrm{Fe}$ 微粒子内包カーボンナノカプセルが合成されると考えられる. 合成された $\mathrm{Fe}$ 微粒子内包カーボンナノカプセルは, アモルファス カーボンなどの不純物とともに, チャンバ内壁, 石英空, $\mathrm{Fe}$ 電極, セラミック皿上に煤状の物質として堆積する. 本実験では, Fe 電 極の下に設置されたセラミック皿上に堆積したものについて, 構 造および磁気特性の評価を行った. 構造の解析には透過型電子顕 微鏡 $(\mathrm{TEM})$, 走査型電子顕微鏡 $(\mathrm{SEM}), \mathrm{X}$ 線回折 $(\mathrm{XRD})$ お よびラマン分光法を使用した. 磁気特性は振動試料型磁力計 (VSM) により評価した.

\section{3. 結果および考察}

Fig. 2 に $P_{\text {total }}=1.0 \mathrm{kPa}$ で合成されたナノカプセルのTEM像を 示寸. Fig. 2(a)から, Fe 微粒子がカーボンの殸に覆われているこ とがわかる. また，矢印の位置に空洞が存在していることが分か る. 本実験においては，このような空洞を持ったナノカプセルが 多数確認されている. Fig. 2(b)はカーボン殼の拡大像である. 層状 の構造が確認出来ることから, カーボン殼は微粒子表面にほぼ平 行なグラファイト層で構成されていることがわかる.これらのグ ラファイト層には, 矢印で示されている部分のように, 久陥や湾 曲している部分が多数存在しており, ファセットの発達度が低い ことがわかる.これは, 比較的低い温度でグラファイト化が進行 したためであると推察される.
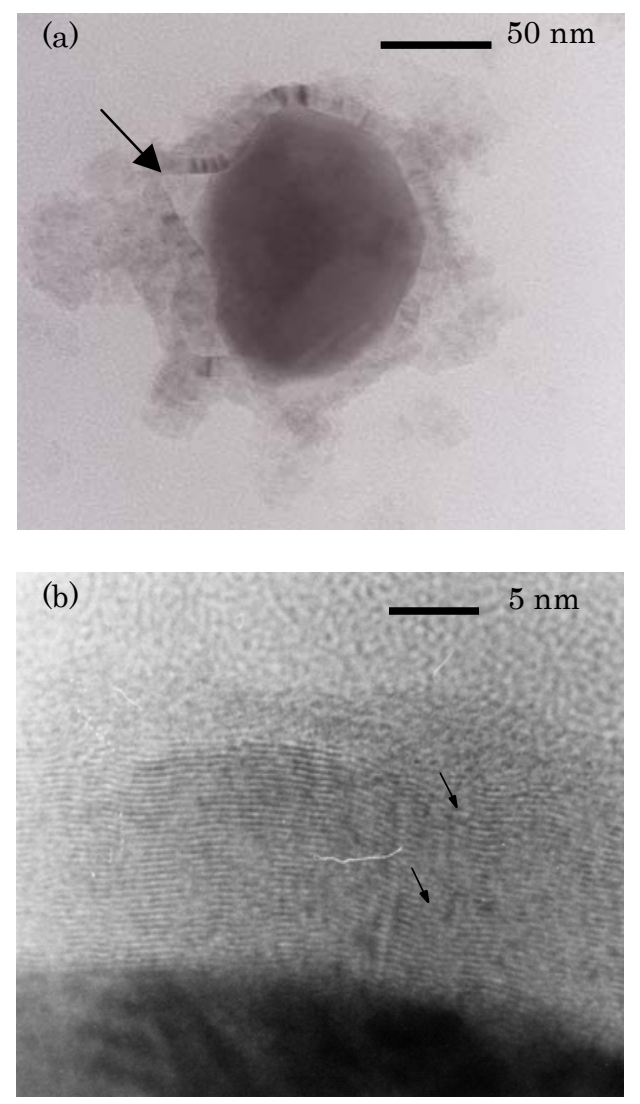

Fig. 2 TEM micrographs of a carbon nanocapsule synthesized under $P_{\text {total }}=1.0 \mathrm{kPa}$ and $I_{\text {arc }}=0.5 \mathrm{~A}$.

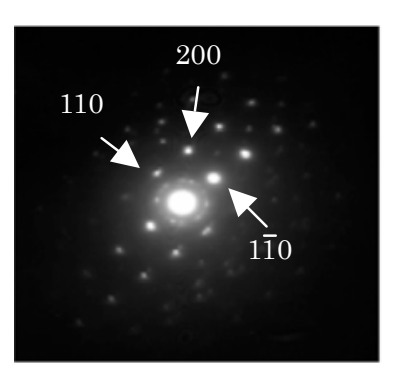

Fig. 3 Selected area diffraction pattern of a carbon nanocapsule synthesized under $P_{\text {total }}=1.0 \mathrm{kPa}$ and $I_{\text {arc }}=0.5 \mathrm{~A}$.

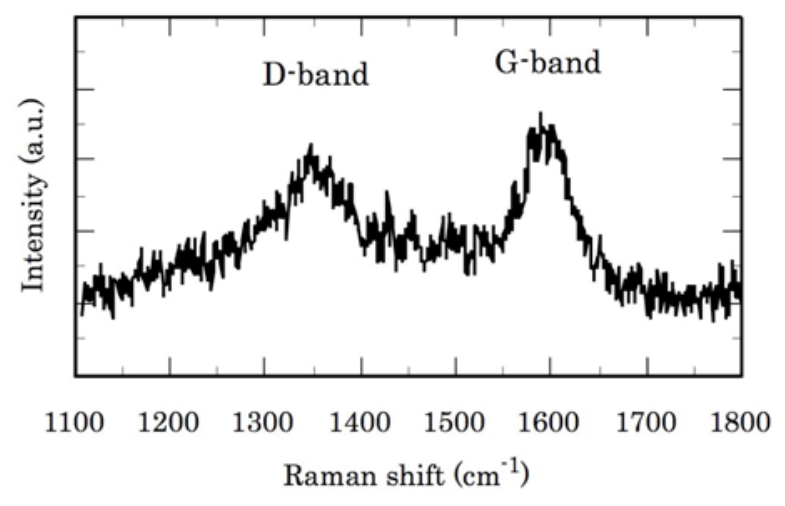

Fig. 4 Raman spectrum.

ナノカプセルに内包されている微粒子の結晶構造を確認するた めに，制限視野回折の測定を行った．結果を Fig. 3 に示寸．測定 したナノカプセルはFig. 2 と同じく $P_{\text {total }}=1.0 \mathrm{kPa}$ で合成された ものである. 中心付近にグラファイトからの回折リングが観測さ れているが，それ以外は明瞭なスポットパターンであり，この微 粒子が単結晶であることを示している. また，それぞれの回折ス ポットは $\alpha-\mathrm{Fe}(110),(200),(1-10)$ 面に対応しており, このナノカ プセルに内包されている微粒子が bcc 構造をとっていることがわ かる.

Fig. 4 はセラミック皿上の堆積物のラマン散乱スペクトルであ り, 合成条件は $P_{\text {total }}=1.0 \mathrm{kPa}$ である. $1590 \mathrm{~cm}^{-1}$ 付近にグラファ イトに由来する G-band が確認でき, $1350 \mathrm{~cm}^{-1}$ 付近にはD-band も同程度の強度で確認できている.このため，合成された堆積物 にはグラファイト層で構成されているナノカプセルとともにアモ ルファスカーボンなどの不純物が含まれていることがわかる.

合成時のガス圧がナノカプセルの構造にあたえる影響を検討す るため, $P_{\text {total }}$ 変化させてナノカプセルを合成し, SEM 像の観察 を行った. ナノカプセルの粒径は不均一であり, 多くは数 $10 \mathrm{~nm}$ 程度から数 $100 \mathrm{~nm}$ 程度であったが，一部，非常に大きな粒径の ナノカプセルが観測された. Fig. 5(a)，(b)，(c)は $P_{\text {total }}=1.5,1.0$, $0.6 \mathrm{kPa}$ で合成されたナノカプセルの SEM 像であり, 確認でき たナノカプセルの中で最大の粒径のものを含む写真である. ガス 圧が高くなるにつれて, ナノカプセルの最大の粒径は増加してお り, $P_{\text {total }}=1.5 \mathrm{kPa}$ では $7 \mu \mathrm{m}$ 程度となっている. ガス圧が増加す ることで, アーク放電により蒸発した Fe の拡散が押さえられ，よ り大きな微粒子が成長しやすくなって，このようなガス圧依存を 示すのではないかと考えている.この結果はガス圧によって平均 


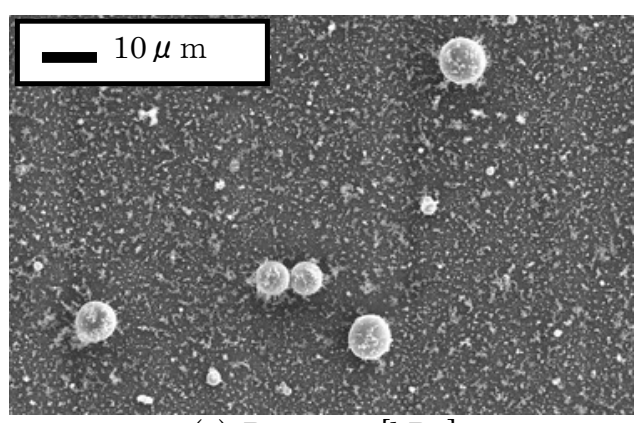

(a) $P_{\text {total }}=1.5[\mathrm{kPa}]$

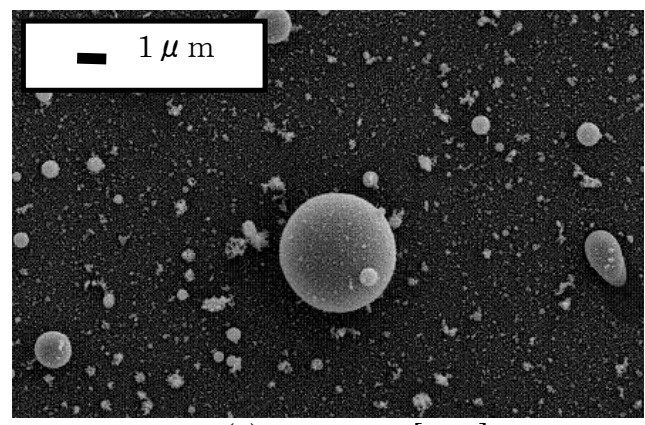

(b) $P_{\text {total }}=1.0[\mathrm{kPa}]$

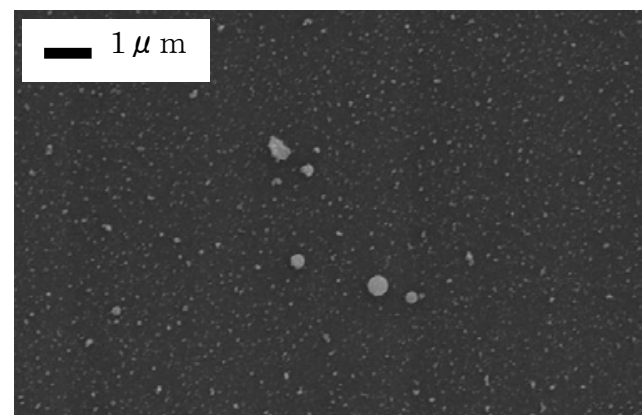

(c) $P_{\text {total }}=0.6[\mathrm{kPa}]$

Fig. 5 SEM micrographs.

粒径を制御できる可能性を示しており，また，通常のアーク放電 法では得られないような，粒径数 $\mu \mathrm{m}$ の非常に大きなカプセルの 合成も可能であることも示している.

次に， $P_{\text {total }}$ を変化させて合成したナノカプセルの XRD パター ンを Fig. 6 に示す. どのガス圧でも $\alpha-\mathrm{Fe}$ と $\gamma-\mathrm{Fe}$ に起因するピー クが観測されている.アーク放電法で作製された微粒子では急冷 効果により $\gamma-\mathrm{Fe}$ が得られることが知られており，本合成方法でも アーク放電法と同様に微粒子の急冷過程が含まれていると思われ る.アーク放電法による実験では, 合成時の He ガス圧が高くなる につれて，高温相である $\gamma-\mathrm{Fe}$ の合成割合が高くなると報告されて いる 5). 本実験でも，Fig. 6 のように，合成時のガス圧によって $\alpha-\mathrm{Fe}$ と $\gamma-\mathrm{Fe}$ の合成比が変化しているように見える. しかしなが ら，現在のところの ' $P_{\text {total }}$ による $\alpha-\mathrm{Fe}, \gamma-\mathrm{Fe}$ 合成比の制御” が 出来るという明確な実験結果は得られていない.

$P_{\text {total }}=1.5,1.0 \mathrm{kPa}$ で合成された微粒子の室温での磁化曲線を Fig. 7 に示寸. Fig. 7(a)はそれぞれの磁化曲線である. どちらも, $5 \mathrm{kOe}$ の印加磁界では磁化が飽和していないことがわかる. $5 \mathrm{kOe}$

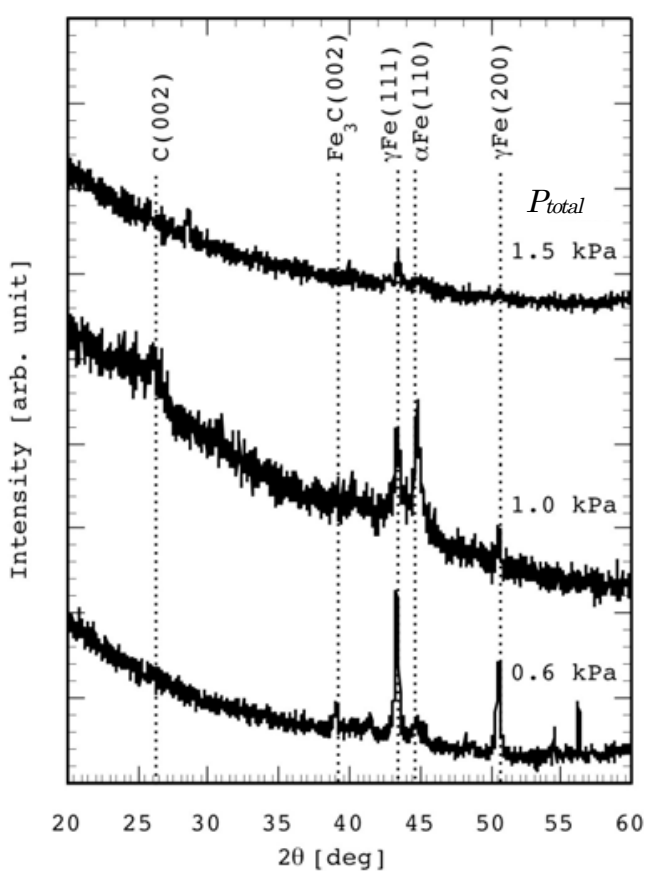

Fig. 6 XRD patterns of nanocapsules.

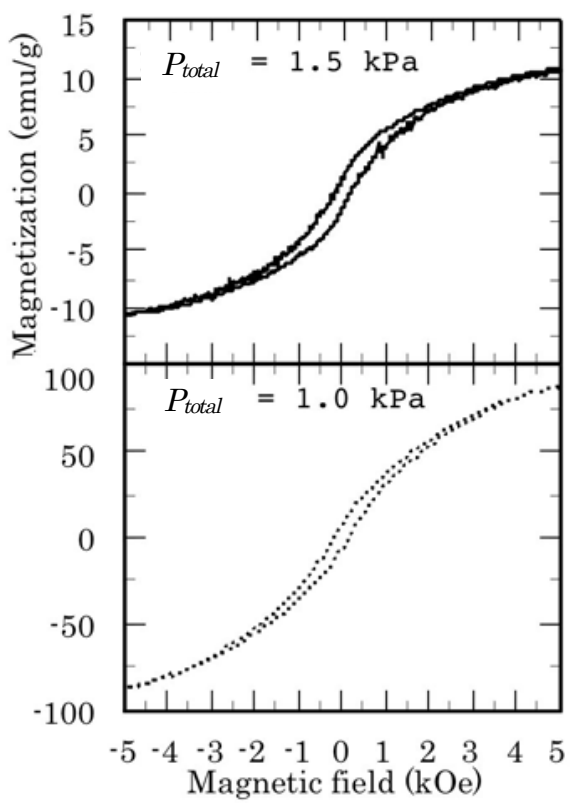

(a)

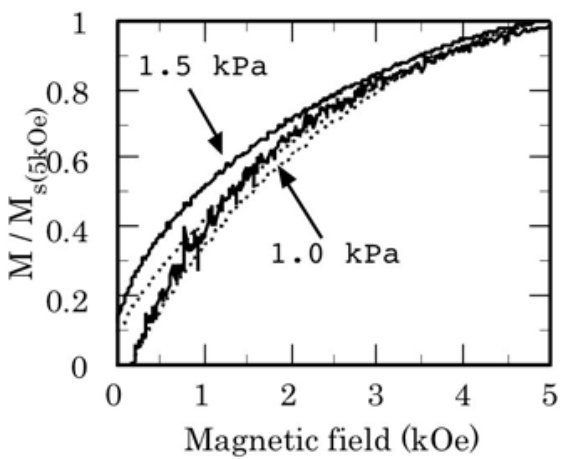

(b)

Fig. 7 Comparison of hysteresis loops. 


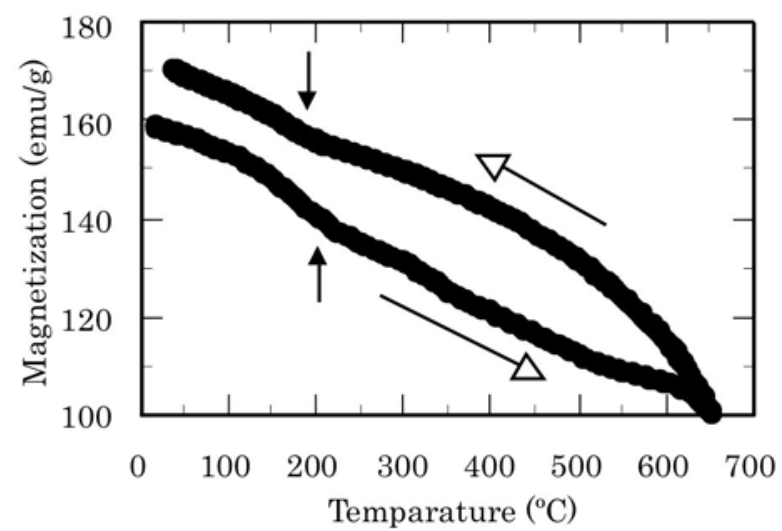

Fig. 8 Temperature dependence of magnetization for nanocapsules synthesized under $P_{\text {total }}=1.0 \mathrm{kPa}$.

での磁化はそれぞれ約 $11 \mathrm{emu} / \mathrm{g}, 88 \mathrm{emu} / \mathrm{g}$ であり, $P_{\text {total }}=1.0 \mathrm{kPa}$ で合成された微粒子が大きな磁化の值を示している. これはXRD の実験結果からも分かるように, $P_{\text {total }}=1.5 \mathrm{kPa}$ で合成された微粒 子の多くが $-\mathrm{Fe}$ であり, $\alpha-\mathrm{Fe}$ 微粒子が非常に少ないことに起因 する. Fig. 7 (b)は磁化曲線の特徵を確認するために, $5 \mathrm{kOe}$ での 磁化で規格化した図である. 保磁力はほぼ同じであるが, $P_{\text {total }}=$ $1.5 \mathrm{kPa}$ の微粒子の磁化曲線の傾きは大きく, また, 若干ではある が残留磁化も大きな值を示し, より強磁生的な傾向を示している. SEM 観察の結果は, $P_{\text {total }}$ が高くなるに従って, 合成される微粒子 の粒径が大きくなる傾向を示している. この結果を考慮すると, $P_{\text {total }}=1.5 \mathrm{kPa}$ で合成された微粒子には, $P_{\text {total }}=1.0 \mathrm{kPa}$ で合成さ れた微粒子よりも, 数は少ないが大きな $\alpha-\mathrm{Fe}$ 微粒子が含まれてい る確率が高いと考えられる. したがって, Fig. 7(b)に示されている 磁化曲線の形状の違いは, 合成された微粒子の粒径の違いを反映 していると考えている.

Fig. 8 に $P_{\text {total }}=1.0 \mathrm{kPa}$ で合成された試料の磁化の温度特性を 示寸. この試料は Fig. 7 に示されている磁化曲線の試料とは別に 作製したものであるため, 室温での磁化の值が違っている. この 時に印加した磁界は $10 \mathrm{kOe}$ である. 昇温過程, 降温過程ともに, 約 $200^{\circ} \mathrm{C}$ で磁化変化の傾向が変わっており, $\alpha-\mathrm{Fe}$ 以外の磁性体の 温度特性を反映したものであると考えられる. このような傾向は アーク放電法で作製されたナノカプセルでも確認されており $4-5)$,

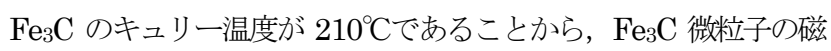
気特性を反映した結果であると結論されている. したがって, こ の結果も同様に $\mathrm{Fe}_{3} \mathrm{C}$ 微粒子の影響であると考えている. 降温過程 では約 $600^{\circ} \mathrm{C}$ 以下になると, 昇温時よりも大きな磁化を示すよう になり, 室温での磁化も昇温前よりも大きな值を示している.こ れは合成直後は $\gamma-\mathrm{Fe}$ であった微粒子が昇温過程で $\alpha-\mathrm{Fe}$ に相変化 を起こしたためであると考えられる. 室温付近まで降温後, 再度 昇温過程での磁化を測定した結果, 1 回目の降温過程とほぼ同じ温 度プロファイルで磁化が変化することを確認した。

この磁化の温度特性の結果から， $\alpha-\mathrm{Fe}, \gamma-\mathrm{Fe}, \mathrm{Fe}_{3} \mathrm{C}$ の合成直 後の含有率をおおまかに見積もると, それぞれ $83 \mathrm{wt} \%, 6 \mathrm{wt} \%$, $11 \mathrm{wt} \%$ となた. ここで, $\alpha-\mathrm{Fe}$ および $\mathrm{Fe}_{3} \mathrm{C}$ の室温での磁化はそ
れぞれ $218 \mathrm{emu} / \mathrm{g} 7), 135 \mathrm{emu} / \mathrm{g}$ 8)であると仮定した. また, $\gamma-\mathrm{Fe}$ 微粒子は磁化 $0 \mathrm{emu} / \mathrm{g}$ の常磁性体であると仮定した ${ }^{9-10)}$. 本実験で 合成された微粒子における $\alpha-\mathrm{Fe}$ に対する $\mathrm{Fe}_{3} \mathrm{C}$ の含有量の比は 0.13 であり, 他の報告 4-5)に比べて非常に小さい值であった. この ことは，本合成方法では，炭化物の生成割合を低く押さえた $\alpha-\mathrm{Fe}$ 微粒子の合成が可能であることを示している.

\section{4. まとめ}

表面波プラズマとアーク放電を利用して，Fe 内包カーボンナ ノカプセルを合成することが出来た. 合成されたカーボンナノカ プセルでは, カーボン殼はグラファイト層で構成されており, 内 包された $\mathrm{Fe}$ 微粒子は単結晶であることが TEM 像の観察より確認 できた. ナノカプセルの粒径は数 $10 \mathrm{~nm}$ から $10 \mu \mathrm{m}$ 程度まで分布 していた. また, 合成時のガス圧を増加させると, 得られるナ, カプセルの最大粒径が増加する傾向にあることがわかった.

$P_{\text {total }}=1.5 \mathrm{kPa}$ で合成したナノカプセルの磁化の值は $P_{\text {total }}=1.0$ $\mathrm{kPa}$ で合成したものより小さな值を示した. また, 磁化曲線の形 状は $P_{\text {total }}=1.5 \mathrm{kPa}$ で合成した方がより強磁性的な特徴を示して いた. この結果は, $P_{\text {total }}=1.5 \mathrm{kPa}$ で合成された微粒子には, $P_{\text {total }}$ $=1.0 \mathrm{kPa}$ で合成された微粒子よりも, 数は少ないが大きな $\alpha-\mathrm{Fe}$ 微粒子が含まれているためであると考えている.

磁化の温度特性の結果を用いて, $\alpha-\mathrm{Fe}$ および $\mathrm{Fe}_{3} \mathrm{C}$ 微粒子の含 有量を見積もったところ，それぞれ 83, 11 wt $\%$ であった. $\alpha-\mathrm{Fe}$ 微粒子に対する $\mathrm{Fe} 3 \mathrm{C}$ 微粒子の割合は他の報告に比べて小さく, 今 回用いた方法により, $\mathrm{Fe}_{3} \mathrm{C}$ 微粒子の生成を押さえて, $\alpha-\mathrm{Fe}$ 微粒 子の合成が可能であることが示された.

\section{References}

1) R. S. Ruoff, D. C. Lorents, B. Chan, R. Malhotra, and S. Subramoney: Science, 259, 346 (1993).

2) M. Tomita, Y. Saito, and T. Hayashi: Jnp. J. Appl. Phys., 32, L280 (1993).

3) Y. Saito, T. Yoshikawa, M. Okuda, N. Fujimoto, S. Yamamuro, K. Wakoh, K. Sumiyama, K. Suzuki, A. Kasuya, and Y. Nishina: Chem. Phys. Lett., 212, 379 (1993).

4) T. Hihara, H. Onodera, K. Sumiyama, K. Suzuki, A. Kasuya, Y. Nishina, Y. Saito, T. Yoshikawa, and M. Okuda: Jnp. J. Appl. Phys., 33, L24 (1994).

5) M. Masuda, K. Maeda, T. Kobayashi, S. Shiomi, Y. Fujiwara, and Y. Saito: Jnp. J. Appl. Phys., 39, L773 (2000).

6) X. F. Zhang, X. L. Dong, H. Huang, Y. Y. Liu, W. N. Wang, X. G. Zhu, B. Lv, and J. P. Lei: Appl. Phys. Lett., 89, 053115 (2006).

7) R. Bozorth: Ferromagnetism, p.867 (D. van Nostrand, New York, 1951).

8) R. S. Tebble and D. J. Craik: Mgnetic Materials, p.90 (Wiley - Interscience, London, 1969).

9) S. Chikazumi, K. Ohta, K. Adachi, N. Tsuya and Y. Ishikawa : Handbook of Magnetic Materials (in Japanese), p.391 (Asakura Shoten, Tokyo, 1975).

10) N. Saegusa, and M. Kusunoki: Jnp. J. Appl. Phys., 29, 876 (1990).

2007 年 10 月 4 日受理, 2007 年 12 月 4 日再受理, 2008 年 2 月 14 日採録 